INFO- 2252

UDK : 342.56

Primljeno / Received: 2021-10-11

Original Scientific Paper

https://doi.org/10.32914/i.55.1-2.6

\title{
IMPARTIALITY IN COURT PROCEEDINGS
}

\author{
Roman I. Blahuta \\ Lviv State University of Internal Affairs, Lviv, Ukraine
}

\begin{abstract}
The importance of the rule of law for the functioning of a democratic state makes this research topic relevant. The study aims to examine the principle of impartiality as one of the key principles of legal procedures, define its place in the provisions of international treaties, international legal acts, and the legislation of Ukraine, and study its interpretation in practice of the European Court of Human Rights. The main research method we used in the article was the formal-legal method, which allowed us to analyze the legal framework of international law, court practice, and the legislation of Ukraine. This, in turn, helped us to examine the level of legal regulation on the principle of impartiality and find out certain gaps. The article explores the practice of the European Court of Human Rights and, on its basis, substantiates as the conclusion the importance of the principle of impartiality in judicial activity. Moreover, having analyzed the legislation of Ukraine, we revealed the need to refine the consolidation of the principle of impartiality and its detailed interpretation in regulatory legal acts, in particular, the Law of Ukraine On the Judiciary and Status of Judges. The practical significance of the article is to prepare the basis for amendments to the legislation of Ukraine.
\end{abstract}

Keywords: the principle of impartiality, the judiciary, the principles of legal procedure, the European Court of Human Rights.

\section{INTRODUCTION}

Nowadays, the rule of law is considered a universal legal value of modern democracies that should not remain just a declarative slogan but should be affirmed at the level of the national legal order. The judicial branch, which is intended to ensure effective protection of violated, unrecognized, or disputed rights, freedoms, and interests of individuals, should significantly contrib-

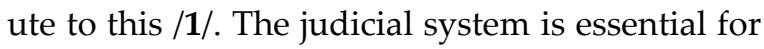
every state, as judges' functions provide for the observance of human rights and uphold the principles of democracy and the rule of law. The justice system is based on the principles recognized by the state and the international community, which ensure the efficiency of judges. Adherence to such principles is a necessary condition for ensuring the realization of the state-guaranteed right to judicial protection for all citizens, regardless of their role in a legal conflict and a lawful, reasonable, and fair court decision.

One of these principles, provided for judges' effective work, is the principle of impartiality. The essence of this principle is the requirement for impartial and fair treatment of each subject of justice. It stipulates that the judge is free from personal beliefs or preferences about the participants in the proceedings when considering the materials of a particular case. His or her actions should exclude any reasonable doubts, i.e., a judge must be objectively impartial /2/. A judge should have no interests except for the proper application of the law. Ensuring the impartiality of judges in court proceedings is the basis for the right to 
judicial protection and the necessary elements of the right to a fair trial for every person.

It should be borne in mind that judges are the same people as other citizens, and therefore, have their own views. Thus, first of all, a judge must possess such personal qualities as courage, justice, honesty. After all, only an objective and impartial court can establish the truth in the case. Thus, impartiality and incorruptibility are the principles of an objective and impartial judge whose decision, taken in the administration of justice, should not cast doubt on its legality and validity $/ 3 /$. The impartiality of the court promotes public confidence in the judiciary and acts as a constitutional and legal guarantee for the protection of human rights and freedoms. At the same time, its level can characterize the development level of the state, which guarantees such protection of rights and freedoms and bases its institutions on the rule of law /4/. Public trust in the court and elimination of prejudice about social or political influence on judges remain relevant questions. The study of the principle of impartiality, its correct legal consolidation, and practical implementation is intended to eliminate such beliefs.

To ensure impartiality, one should have theoretical comprehension of its concept, determinate its content and relationship with other legal categories that provide for the right to a fair trial /5/. Moreover, impartiality is not considered as an independent legal category in science so far. Traditionally, its definition is interpreted within the principle of independence of judges and the common right to a fair trial. At first glimpse, impartiality as a term seems quite clear. However, while analyzing the rules on the status of judges, the procedure for appointing judges, and the civil process itself, it becomes evident ensuring impartiality requires additional special regulation. Even long-established rules on the dismissal of judges contain certain problems that do not provide these rules with the necessary guaranteeing role. Based on the above, the article aims to examine the principle of impartiality as one of the key principles of legal procedures, define its place in the provisions of international treaties, international legal acts, and the legislation of Ukraine, and study its interpretation in practice of the European Court of Human Rights.

In the course of the research, we applied a system of general scientific, philosophical, and special methods, which allow obtaining reliable results and achieving the set aim. Methods of scientific knowledge are used to study the characteristics of the judicial branch in terms of its operating principles. The formal-legal method is used to analyze the principles of justice, namely impartiality of judges, within legal acts, the practice of the European Court of Human Rights, the Law of Ukraine. The system method allowed us to generalize information on the features of the principle of impartiality. With the method of analysis and synthesis, we processed theoretical information, international legal acts, case law and, on their basis, identified problems existing in the research area and ways to solve them.

\section{GENERAL THEORETICAL APPROACHES TO THE PRINCIPLE OF IMPARTIALITY}

The right to a fair trial plays a significant role among other human rights as the main principle of protection of rights is that every violated right can and should be restored. Furthermore, a fair court cannot function without adherence to the basic principles of justice, and the principle of impartiality is among them.

Impartiality is most evident in procuring evidence, being expressed in the following actions of the court: determination of the subject of proof; apportionment of the burdens between the parties; submission, disclosure, and provision of evidence; choice of methods and means of proof; study and evaluation of evidence. When procuring evidence lacks impartiality, the requirements for correspondence, admissibility, reliability, and sufficiency of the evidence, principles of procedural equality, and adversarial nature of the parties are violated. This leads to unfounded court conclusions outlined in the court decision. 
One of the components of justice is the lack of prejudices against facts in a case. The judge shall abstract from the negative influence of external factors. A judge's opinion shall base on the evidence available in the case, internal conviction, guided by the law and conscience /6/. The court decision, especially its motivation part, helps to conclude on the impartiality of a judge. The lack of impartiality often leads to such violations as the inconsistency between the conclusions of the first-instance court set out in the court decision and circumstances of the case. They are the grounds for the reversal of judgment /7/.

The rule of law is an important factor for the state to function effectively. Therefore, it is paid a lot of attention at the international legal level, especially regarding the principles of judicial activity and impartiality. Let's consider some international legal acts that regulate this issue. First of all, we should note the Universal Declaration of $\mathrm{Hu}-$ man Rights of 1948 /8/, where Article 10 states: "Everyone is entitled in full equality to a fair and public hearing by an independent and impartial court, in the determination of his rights and obligations and any criminal charge against him". Subsequently, the provisions of the declaration, which by its nature was declarative, were enshrined in the International Covenant on Civil and Political Rights of 1966/9/, which was already binding. Specifically, namely Art. 14 of the Covenant emphasized the common right to a "fair and public hearing by a competent, independent and impartial court established by law".

The Basic Principles on the Independence of the Judiciary, adopted by the Seventh United Nations Congress on the Prevention of Crime and the Treatment of Offenders of $1985 / \mathbf{1 0} /$, states that the judiciary shall decide matters before them impartially, basing on facts and under the law, without any restrictions, improper influences, inducements, pressures, threats or interferences, direct or indirect, from any party or for any reason.

The Human Rights Committee in González del Rio v. Peru, 1992 /11/, specified that the human right to be tried by an independent and impartial court is an absolute right that may suffer no exception. Thus, we can conclude that all courts, both general and special jurisdiction, should adhere to this principle in all circumstances. The next international legal act of universal level is the Bangalore Principles of Judicial Conduct, 2006 /12/. The principles were adopted by Resolution No. 2006/23 of UN Economic and Social Council (hereinafter - ECOSOC). Although they do not single out impartiality as a principle, almost every explanation of the Bangalore Principles indicates the need for impartial consideration of the case. For example, paragraph 2.4 states: "The judge shall make any comment in public or otherwise that might affect the impartial trial of any person or issue."

Paragraph 2.5 contains the important provision, which states that a judge must dismiss himself from the office if a matter of his impartiality arises and specifies cases where doubts of his impartiality may be relevant. These cases are as follows: a judge has a real prejudice against a party; a judge previously served as a lawyer or was a material witness in consideration of the same matter in controversy; a judge, or a member of the judge's family, has an economic interest in the outcome of the matter in controversy /12/. The Council of Europe also pays attention to impartiality in court proceedings. Thus, Art. 6 of the Convention for the Protection of Human Rights and Fundamental Freedoms, 1950 /13/, claims: "Everyone has the right to a fair and public hearing within a reasonable time by an independent and impartial tribunal established by law, which will determine his civil rights and obligations and establish the validity of any criminal charge against him".

The European Court of Human Rights (hereinafter - the ECtHR) confirms the above once again. Proceeding special cases, the ECtHR indicates that human and civil rights can be effectively protected only if the court is objective. Thus, in his Judgment in Findley v. The United Kingdom, 1997, the Court found that the military tribunal had violated Article 6 of the Convention for the Protection of Human Rights and Fundamental Freedoms of 1950 as the applicant was not given 
a fair hearing by an independent and impartial tribunal. However, the ECtHR stated that one should consider two aspects to claim a court "impartial." First, the court must be subjectively free from personal beliefs or preferences. Secondly, it must be objectively impartial, i.e., to guarantee to exclude any legitimate doubt in this respect /14/.

The analysis of the ECtHR case law allows us to conclude that regarding the conventional system of protection, the independence and impartiality of the court as components of the rule of law are primarily linked with procedural guarantees for the right to a fair trial. Thus, the emphasis is made on the procedural rather than a judicial aspect of these notions $/ \mathbf{1 5} /$. The case of Sener v. Turkey of 2000 allows considering impartiality through the official position of a judge. Thus, the ECtHR ruled that accused may have reasonable doubts about the judge's impartiality if he is subordinate to one of the parties in terms of his responsibilities and work organization /16/.

In Micallef v. Malta, 2009, the ECtHR distinguished two main criteria to revise a judge's impartiality: subjective and objective. The first criterion concerns the personal views and beliefs of the judge, his behavior, i.e., whether the judge holds any personal prejudices, as well as the level of his objectivity in the case. The second criterion is that the court composition must provide sufficient guarantees to exclude any legitimate doubt in its impartiality /17/. Concerning another case, the ECtHR emphasized the difficulty in obtaining evidence of subjective bias. The reason is that issues of court bias have been mainly concerned the objective bias $/ \mathbf{1 8} /$.

Thus, in Sovtransavto Holding v. Ukraine, 2002, the President of Ukraine sent a letter to the President of the Supreme Arbitration Court, which called "to protect the interests of the citizens of Ukraine" and "the interests of the state." In turn, the President of the Supreme Arbitration Court addressed this letter to the Arbitration Court of Kyiv Oblast so that its President could take it into account in the case hearing. Confused by such a disregard for the principle of separation of powers, the ECtHR noted that these "numerous interventions in the proceedings ... are incompatible with the notion of an independent and impartial tribunal ... and indicate that authorities lack respect for the judiciary" /19/.

The ECtHR delivered the judgment on the Bochan v. Ukraine case of 2007 /20/, in which Ukraine was also a party. It considered the special circumstances under which the Supreme Court of Ukraine changed its territorial jurisdiction and found the lack of proper and complete justification of national courts decisions. Relying on the above, the ECtHR concluded that the applicant's right to a fair trial by an independent and impartial tribunal, enshrined in Article $6 \S 1$ of the European Convention on Human Rights, was violated. Moreover, in this case, the ECtHR used the subjective and objective criteria to define impartiality with regard to Art. 6 of the European Convention on Human Rights. The subjective criterion is based on the personal convictions and conduct of a particular judge, that is, each court member shall not show any personal commitment or prejudice. The objective criterion is to establish whether a judge has sufficient guarantees to exclude any legitimate doubt in his impartiality. The objective criterion must determine whether there are verifiable facts that cast doubt on the lack of impartiality of the courts. In this regard, even external facts have some significance. The key issue is confidence, which the courts should inspire in society and, above all, the parties of proceedings.

Thus, according to the legal positions set out in the judgments of the ECtHR, the Court understands impartiality as the absence of bias and interest in the case outcome. Assessing its importance in terms of a fair trial, the ECtHR has repeatedly emphasized the courts in a democratic society must instill public confidence. Therefore, it is necessary that judges be not only impartial but also look like that. Consequently, the ECtHR, examining the impartiality of judges, divides between the subjective approach, which reflects the personal convictions of each judge in a particular case, and the objective one, which determines 
whether there are sufficient guarantees to exclude any legitimate doubt in this regard.

As the judges of the European Court of Human Rights summarized in the judgment in Buscemi v. Italy of $\mathbf{1 9 9 9} / \mathbf{2 1}$ /, the personal (subjective) impartiality of a judge is presumed until proven otherwise. Conversely, to prove the violation of objective ground of impartiality, one need not establish directly that a judge had a bias or a personal interest in a case outcome. Judges must behave in such a way that the participants in the proceedings and those present have no objective grounds to doubt the court impartiality. Moreover, the ECtHR believes that those who claim the judge to be biased are important but not decisive to conclude about legitimate grounds for such fear in this case. However, a critical issue arises: can such fears be considered as objectively justified?

It is also worth noting that the European Court of Human Rights emphasizes that the principles of impartiality and independence are closely linked and often difficult to separate. Especially it concerns these situations when the applicant's arguments on the lack of independence and impartiality of the court are based on one and same facts, such as in the case of the Klein and Others v. The Netherlands case, 2003 /22/.

\section{THE PRINCIPLE OF JUDICIAL IMPARTIALITY IN INTERNATIONAL LAW}

Regarding the relevant decision, in Opinion No.1 (2001) for the attention of the Committee of Ministers, the Consultative Council of European Judges emphasized that the independence of the judiciary means complete impartiality of judges. When making judgments about the parties to a trial, judges must be impartial, free from any connection, inclination, or bias, which affect or may be perceived as affecting their ability to make independent judgments. In this regard, the independence of the judiciary is the embodiment of the fundamental principle that "no one may be a judge in his own case." This principle has value far beyond the specific interests of the particular parties to any dispute $/ \mathbf{2 3} /$.
For example, in the case of Belukha v. Ukraine, $2006 / 24 /$ the ECtHR found that the President of the Court, who had heard the applicant's case as a court of the first instance, had demanded and received certain property from the defendant company free of charge (for the court as a whole). The ECtHR considered that the applicant's fears that the President of the Court would be biased could have been objectively justified in these circumstances. Regarding another case, Kabanov v. Russia, 2011 /25/ the ECtHR concluded that the applicant's doubts about the impartiality of the entire Regional Court were objectively justified. The reason for such a decision was that the President of the said court, in fact, initiated the disciplinary proceedings against the applicant (who was a lawyer)., as the chairman of that court had in fact instituted disciplinary proceedings against the applicant (who was a lawyer). The Council of the Regional Bar Association had made a judgment to deprive the applicant of his status, and subsequently, when the applicant appealed this decision to the court, it was the President of the Court, who under his organizational and managerial functions, determined the court composition and referred the case to it.

The ECtHR has also repeatedly commented on the minimum necessary guarantees to ensure the impartiality of judges. In particular, the ECtHR believes when there is a claim on the question of the impartiality of a judge (judges), the national judicial body is obliged to examine in each case whether the relevant court is impartial as following Art. 6 of the Convention for the Protection of Human Rights and Fundamental Freedoms /26/. Moreover, such examination must be effective and eliminate doubts about the reality and nature of these facts. If the examination results in justification of doubts about the impartiality of a judge, then any judge whose impartiality is legitimately doubted must resign from the court.

Adopted by the Venice Commission in 2016, the Rule of Law Checklist states that the judiciary should be independent and impartial, where impartiality means that the judiciary - even on the surface - does not appear to be biased in the case 
outcome $/ 27 /$. On the one hand, impartiality is a subjective category, which depends on subjective factors. On the other hand, it is objective, formed under the objective conditions that ensure its manifestation /28/. Among the documents adopted within the Council of Europe, it is also worth noting the European Charter on the Status for Judges, 1998. This European Charter is a document of a recommendatory nature. However, all the issues addressed by the Council of Europe in its internal legal acts are relevant nowadays. and Therefore, the adoption of the Charter proves that the issue of justice and the judicial system of European countries is immediate and needs to be clarified. The adoption of the European Charter was the need for an official document intended for all European states, which would set out provisions aimed at ensuring the highest guarantees of competence, independence, and impartiality of judges.

The principle of impartiality takes an important place among the provisions of the Charter. Almost all provisions state the principle of impartiality should be as a guideline in all issues, including a candidate for a judge, the procedure for selecting a candidate, a judge directly in the office. Under paragraph 1.1 of the European Charter: "the statute for judges aims at ensuring the competence, independence, and impartiality which every individual legitimately expects from the courts of law and from every judge to whom is entrusted the protection of his or her rights. It excludes every provision and every procedure liable to impair confidence in such competence, such independence, and such impartiality" /29/. The European Charter aims to ensure the competence, independence, and impartiality that every person legitimately expects from the court and every judge who protects his or her rights. It should not contain provisions and procedures that could impair confidence in such competence, independence, and impartiality. Other international organizations have also gotten in on the legal consolidation of such an important principle of justice. For example, paragraph 1 of Art. 7 of the African Charter on Human and Peoples' Rights, adopted by the Organization of African
Unity (now the African Union) in 1981, states that every person has the right to a fair trial within a reasonable time by an impartial tribunal /30/.

As it states in Art. 8 of the American Convention on Human Rights, developed and adopted by members of the Organization of American States in 1969, every person has the right to have his or her case heard with due guarantees and within a reasonable time, by a competent, independent, and impartial tribunal, previously established by law to substantiate any criminal charge against him or her for determination of his or her rights and obligations of a civil, labor, fiscal, or any other nature $/ 31 /$. Thus, key international conventions on human rights of the regional level also contain a rule recognizing the need for the court to adhere to the principle of impartiality. We should note that the above list of international legal acts is not exclusive and can be supplemented by other international documents that support the importance of the principle of impartiality in judicial activities.

\section{REGULATION OF THE PRINCIPLE OF IMPARTIALITY IN THE LEGISLATION OF UKRAINE}

Considering the legislation of Ukraine on this issue, one cannot ignore the Constitution of Ukraine of 1996 as a fundamental legal act because it forms the basis of the legal system of Ukraine, in particular the justice system. According to Art. 34 of the Constitution of Ukraine, which regulates human rights, “... the exercise of such rights may be restricted by law in the interests of ... supporting the authority and impartiality of justice" /32/. However, this is the only provision on the principle of impartiality in the Constitution of Ukraine. Although the Constitution of Ukraine contains a whole section on the judiciary and the judicial system of Ukraine, it does not regulate the principle of impartiality.

It is important to consider the opinion of V.V. Horodovenko /33/, the Judge of the Constitutional Court of Ukraine, regarding the Decision of the Grand Chamber of the Constitutional Court of Ukraine in the case upon the constitutional 
petition of 55 People's Deputies on the conformity of Article 375 of the Criminal Code with the Constitution of Ukraine (constitutionality). The Judge states that the judge's sincere conviction as to the legitimacy of his activity is his independence and impartiality, and consequently, the essence of justice as such. He further notes that "judges should have unrestricted freedom to impartial trials under the law and their own understanding of the facts." The judge also highlights that the court decision should be based on the principles of the rule of law, impartiality, independence, adversarial proceedings, and equality of all participants in the trial (the opinion of the Judge of the Constitutional Court of Ukraine V.V. Horodovenko regarding the Decision of the Grand Chamber of the Constitutional Court of Ukraine in the case upon the constitutional petition of 55 People's Deputies on the conformity of Article 375 of the Criminal Code with the Constitution of Ukraine (constitutionality), 2020). That is, in fact, V.V. Horodovenko once again stressed the need to comply with all fundamental principles of justice. However, we should consider this opinion in our analysis as it was suggested regarding the case of 2020. As the issue of the principles of justice arises in new cases, this problem has not disappeared in the Ukrainian judiciary, and therefore, the study of the principle of impartiality is still relevant.

There is no principle of impartiality as the basis of justice in the Code of Civil Procedure of Ukraine (hereinafter - CCP of Ukraine) dated 2004. However, Art. 2 of the CCP of Ukraine states that the task of civil legal proceedings is fair, impartial, and timely trial and solution of civil cases, aimed at effective protection of violated, unrecognized or disputed rights, freedoms, and interests of physical persons, rights and interests of legal entities, interests of the state /34/. The Law of Ukraine On the Judiciary and Status of Judges, dated 2016 /35/, is an important legal act in Ukraine. In particular, Art. 57 of the Law states the need for taking the judicial oath, which contains the following words: "... taking this office of a judge, do solemnly swear to Ukrainian people to administer justice objectively, fairly, impartially, independently, justly and in a highly qualified manner in the name of Ukraine, following the principle of the rule of law..." In addition, the Law of 2016 mentions the principle of impartiality in various aspects several times. However, as in the Constitution of Ukraine, it is not mentioned separately as a basic principle of the administration of justice. There is also no definition of it in the legislation.

Thus, even though the principle of impartiality is provided in international legal acts, it is not properly regulated in the national legislation of Ukraine. This is a problem, as improper regulation of the principles of the judiciary activity in domestic legal acts can lead to their misunderstanding. The above opinion of Judge V.V. Horodovenko /36/ proves it (the opinion of the Judge of the Constitutional Court of Ukraine V.V. Horodovenko regarding the Decision of the Grand Chamber of the Constitutional Court of Ukraine in the case upon the constitutional petition of 55 People's Deputies on the conformity of Article 375 of the Criminal Code with the Constitution of Ukraine (constitutionality), 2020).

Indeed, the principle of impartiality is given a lot of attention in international legal acts and recommendations, which, at first glance, may show that their duplication in Ukrainian legal acts is not needed. However, we believe that domestic regulations should explain such a fundamental principle for its detailed understanding and proper application. We believe an article that would enshrine the principles of justice, including the principle of impartiality, can be added to the Law of Ukraine On the Judiciary and Status of Judges, dated $2016 / 37 /$. For example, in the Law of Ukraine, there is Art. 6 Independence of Courts. We believe that the principle of impartiality can be added and explained on its basis. Moreover, as noted earlier, the ECtHR emphasized their relationship in the judgment in Klein and Others v. The Netherlands, dated 2003 /38/. Therefore, such an addition to the article will be quite logical and of practical significance. Moreover, the consolidation of the principle of impartiality along with its interpretation in the legislation of Ukraine will settle disputes in international legal science and 
reduce the diversity of definition of impartiality in the judiciary.

Many researchers have considered the issue of impartiality of judges in their works. The Ukrainian researcher made an important contribution to the study of this issue. In her scientific work, she explored the essence of impartiality in judicial practice and analyzed its relationship with the principle of independence /39/. Other Ukrainian scholars, T.I. Fulei and A.M. Kuchiv /40/ conducted a fundamental study based on the case law of the European Court of Human Rights concerning Art. 6 of the Convention for the Protection of Human Rights and Fundamental Freedoms. They collected and researched a number of cases concerning the principle of impartiality. This work is interesting as it explains the attitude of the ECtHR to the principle of impartiality, identifies its types and the grounds for doubts about impartiality, etc.

The Ukrainian researcher V.O. Hryniuk /41/ not only analyzed the principle of impartiality but also examined it according to the Ukrainian legislation and realities of our legal system. He argued that the impartiality of judges could remain a declarative provision if the state did not have the necessary mechanisms to ensure it. The researcher also considered the guarantees for judicial impartiality and independence, their application in Ukraine, and the legal basis of the issue.

N.M. Hren $/ 42 /$, the Ukrainian researcher, also considered the issue of the court impartiality through the right to a fair trial. She notes that the impartiality of the court is a mandatory requirement of the rule of law. The researcher points out if this principle is not ensured, the trial will become a farce, and the judiciary - a puppet in the hands of stakeholders. Thus, she justifies the need to adhere to the principles of justice. Also, unlike most scholars, she divides the independence and impartiality of the judiciary into two separate but interrelated principles, noting that the first one applies to the overall judiciary, and the second, in turn, applies to each case. Regarding the principle of impartiality, she distinguishes two components: a judge must be subjectively impartial in hearing the case, i.e., must have no personal interest or bias; a judge must be objectively impartial, that is, must provide sufficient guarantees to exclude any legitimate doubt in this regard. The impartiality of the judge's personality towards a specific participant in the trial and the case outcomes are highlighted.

N.V. Hlinska /43/ deeply studies the principles of impartiality and their importance for the judicial system of Ukraine. At the same time, she emphasizes that only a collective, situational (depending on the circumstances of a particular proceeding) assessment of all factors of bias by a competent entity can be a ground for establishing the bias of a party. Separate aspects of guarantees of the court impartiality were studied by E.T. Barbakadze /44/, I.V. Rekhtina /45/, Yu. Romaniuk /46/, I.Yu. Tatulych /47/, Yu.V. Shapovalova /48/, and others. Although many scientists have devoted their works to this issue, it remains insufficiently researched and debatable in legal science. In particular, insufficient attention is paid to the compliance of domestic legal norms with international legal requirements and standards /49/. Moreover, we emphasized the case law of the European Court of Human Rights, having comprehensively interpreted and discussed the principles of impartiality in court decisions.

\section{CONCLUSION}

The rule of law and the impartiality of judges are inextricably linked and complementary. In this case, the first is a prerequisite and condition of the second, although it cannot serve as its sufficient guarantee. If the court is impartial, it promotes public confidence and acts as a constitutional and legal guarantee for the protection of human rights and freedoms. Impartiality, being the moral quality of the judge and the requirement for his behavior in the proceedings, is a condition for justice and directly relates to it. At the same time, the impartiality of the court corresponds to independence, but it is not identical to it. Impartiality determines the decision-making process, and independence depends on the court composition, the conditions for judges' career, i.e., 
organizational factors and the judiciary. Independence does not guarantee impartiality but is an important prerequisite for its existence. In fact, there are situations when an independent judge, without any outside influence, makes his biased decision.

The basic significance of the court impartiality is that it can be unequivocally recognized as one of the conditions for fair justice. An impartial judge aims at achieving justice. This is the meaning of justice and its significance for society. The impartiality of a judge is determined by both the degree of independence of the judiciary and the managerial influences from the judiciary itself. Based on this, the independence of the judicial system implies management processes within it. Hence, higher levels of this system can influence the lower ones. The above proves that the judicial system, to ensure a sufficient level of impartiality, should be structured as that judges of higher courts cannot unduly influence judges of lower courts, namely their right and duty to decide cases according to their inner conviction. In the modern state, the effective exercise of judicial power by impartial judges acquires more significance as justice is intended itself to ensure human rights and freedoms, that is, to be their guarantor.

The provisions of international legal acts that enshrine this principle and the practice of the ECtHR confirm its importance for the functioning of the judicial system. Key international conventions on human rights of the universal and regional levels contain a rule recognizing the need for the court to adhere to the principle of impartiality. The European Court of Human Rights states in its decisions that the personal impartiality of a judge is presumed until proven otherwise. Judges should behave as that the participants have no reason to doubt their impartiality. However, unlike international norms and standards, the legislation of Ukraine, although referring to impartiality as a principle of justice, does not specifically define it in legal acts. We believe that this significant omission gives rise to many inaccuracies and discussions.
To eliminate doubts about the impartiality of judges, we propose to improve legislation by introducing additional guarantees in the form of a rule, according to which the case is transferred to another court. We also urge developing updated guidelines for domestic judges, taking into account the norms and recommendations of international law, the requirements of domestic law, and the realities of the Ukrainian judicial system. It also seems necessary to amend the Law of Ukraine On the Judiciary and Status of Judges dated 2016 with a provision on the principle of impartiality.

The theoretical significance of the study is that the obtained results and the conclusions based on them promote the science of procedural law and identify problems in judicial activity. The practical significance of the study is manifested in the suggested recommendations aimed at improving the domestic legislation on the regulation of the principle of court impartiality. In particular, we proposed to explain this principle in Art. 6 of the Law of Ukraine On the Judiciary and Status of Judges and in the ECtHR case law on such violations, which shows the main directions the European countries, including Ukraine, should follow to eliminate any violations of impartiality in judicial activity.

Notes

/1/ Tsuvina, T.A. (2019), Independence and impartiality of the court as components of the rule of law in civil proceedings. Theory and Practice of Law, 2(16), 1-10.

/2/ Trubnikova, T.V. (2013), The cob is not ahead of the court in the criminal process: neglect is undeserved. Russian Journal of Criminal Law, 1(11), 51-55.

13/ Iliutchenko, N.V. (2018), Conflict of interest in the work of judges. Notary Gazette, 1, 50-52.

/4/ Filin, D.M., \& Borovkov, A.V. (2015), The place and role of moral principles in the work of a judge. Issues of Modern Jurisprudence, 44 years old, 3-19.

15/ Savchenko, A.R. (2019), The right to a fair trial in criminal proceedings: problems of publicity, impartiality and independence of the court. Young Scientist, 23, 536-541.

16/ Drozdov, O. (2020), Independence of justice: what vector of development for Ukraine is given by the practice of the ECHR. Retrieved from 
https://www.echr.com.ua/nezalezhnist-pravosuddya-yakij-vektor-rozvitku-dlya-ukra\%D1\%97nidaye-praktika-yespl/

/7/ Hryniuk, V.O. (2012), Guarantees to ensure the independence of the court. Criminal Proceedings, 5, 131-135.

/8/ United Nations General Assembly. (1948), The Universal Declaration of Human Rights. Retrieved from https://www.un.org/ru/documents/decl_conv/declarations/declhr.shtml

19/ United Nations General Assembly. (1966), International Covenant on Civil and Political Rights. Retrieved from https://www.un.org/ru/documents/decl_conv/conventions/pactpol.shtml

/10/ United Nations General Assembly. (1985), Basic Principles of the Integrity of the Judicial Authorities. Retrieved from https://www.un.org/ru/documents/decl_conv/conventions/indep.shtml

/11/ Human Rights Committee. (1992), González del Rio vs. Peru. Retrieved from https://www.ohchr.org/Documents/Publications/SDecisionsVol4ru.pdf

/12/ Judicial Group on Strengthening Judicial Integrity. (2006), Bangalore principles of judicial conduct. Retrieved from https://www.unodc.org/documents/ji/training/bangaloreprinciples.pdf

/13/ Council of Europe. (1950), Convention for the Protection of Human Rights and Fundamental Freedoms. Retrieved from https://zakon.rada.gov.ua/laws/show/995_004\#Text

114/ European Court of Human Rights. (1997), Case of Findlay v. The United Kingdom. Application No. 22107/93. Retrieved from http:/hudoc.echr.coe.int/app/conversion/pdf/?library $=$ ECHR\&id=001-58016\&filename $=001-$ 58016.pdf

/15/ op. cit. in /1/

/16/ European Court of Human Rights. (2000), Case of Sener v. Turkey. Application No. 26680/95. Retrieved from http://hudoc.echr.coe.int/app/conversion/pdf/?library $=$ ECHR\&id $=001$ 59081\&filename=001-59081.pdf\&TID=thkbhnilzk

/17/ European Court of Human Rights. (2009), Case of Micallef v. Malta. Application No. 17056/06. Retrieved from https:/hudoc.echr.coe.int/fre\#\{\%22itemid \%22:[\%22002$1270 \% 22]\}$

118/ European Court of Human Rights. (2015), Case of Morice v. France. Application No. 29369/10. Retrieved from https:/hudoc.echr.coe.int/fre\#\{\%22itemid\%22:[\%22001$154265 \% 22]\}$
/19/ European Court of Human Rights. (2002), Case of Sovtransavto Holding v. Ukraine. Application No. 48553/99 . Retrieved from https:/hudoc.echr.coe.int/fre\#\{\%22itemid \%22:[\%22002$5236 \% 22]\}$

/20/ European Court of Human Rights. (2007), Bochan v. Ukraine. Application No. 7577/02. Retrieved from https://zakon.rada.gov.ua/laws/show/974_209\#Text

/21/ European Court of Human Rights. (1999), Case of Buscemi v. Italy. Application No. 29569/95. Retrieved from https:/hudoc.echr.coe.int/eng\#\{\%22itemid \%22:[\%22001$58304 \% 22]\}$

/22/ European Court of Human Rights. (2003), Kleyn and Others v. the Netherlands. Applications No. 39651/98, 39343/98, 46664/99. Retrieved from https://hu-

doc.echr.coe.int/fre\#\{\%22itemid\%22[\%22002$4870 \% 22]\}$

/23/ Opinion No. 1 of the Consultative Council of European Judges for the attention of the Committee of Ministers of the Council of Europe on Standards for the Independence of the Judiciary (2001), Retrieved from https:/zakon.rada.gov.ua/laws/show/994_a52\#Text

/24/ European Court of Human Rights. (2006), Case of Belukha v. Ukraine. Application No. 33949/02. Retrieved from https:/hudoc.echr.coe.int/fre\#\{\%22itemid \%22:[\%22001$77950 \% 22]\}$

/25/ European Court of Human Rights. (2011), Case of Kabanov v. Russia. Application No. 8921/05. Retrieved from https:/hudoc.echr.coe.int/fre\#\{\%22itemid \%22:[\%22001$103222 \% 22]\}$

/26/ European Court of Human Rights. (2007), Case of Farhi v. France. Application No. 17070/05. Retrieved from https://www.echr.coe.int/documents/hrtf_cases_list_russia_eng.pdf

/27/ The Venice Commission at its 106th Plenary Session. (2016), Rule of Law Checklist. Retrieved from https://www.venice.coe.int/webforms/documents/default.aspx?pdffile=CDL-AD(2016)007e

/28/ Moiseieva, T.V. (2003), Ensuring the impartiality and objectivity of judges in criminal cases. Journal of Russian Law, 6. Retrieved from http://www.echr.ru/news/msg.asp?id_msg=153\#: $\sim:$ text $=\%$

/29/ Council of Europe. (1998), European Charter on the Status for Judges. Retrieved from https://zakon.rada.gov.ua/laws/show/994_236\#Text 
130/ The African States members of the Organization of African Unity. (1981), African Charter on Human and Peoples' Rights. Retrieved from http://hrlibrary.umn.edu/russian/instree/Rz1afchar.html

/31/ Organization of American States. (1969), American Convention on Human Rights. Retrieved from https://constituanta.blogspot.com/2011/02/1969.html

/32/ Constitution of Ukraine. (1996), Document No. 254k / 96-BP. Retrieved from https://zakon.rada.gov.ua/laws/show/254\%D0\%BA/96$\% \mathrm{D} 0 \% \mathrm{~B} 2 \% \mathrm{D} 1 \% 80 \#$ Text

/33/ A separate opinion of the Judge of the Constitutional Court of Ukraine V.V. Horodovenko regarding the Decision of the Grand Chamber of the Constitutional Court of Ukraine in the case upon the constitutional petition of 55 People's Deputies on the conformity of Article 375 of the Criminal Code with the Constitution of Ukraine (constitutionality). (2020), Document No. ng07d710-20. Retrieved from https://zakon.rada.gov.ua/laws/show/ng07d710-20\#Text

/34/ Verkhovna Rada of Ukraine. (2004), Civil Procedural Code of Ukraine No. 1618-IV. Retrieved from https://zakon.rada.gov.ua/laws/show/161815\#Text

135/ Verkhovna Rada of Ukraine. (2016), Law of Ukraine On the Judiciary and Status of Judges No. 1402-VIII. Retrieved from https://zakon.rada.gov.ua/laws/show/1402-19\#Text

/36/ op. cit. in /33/

/37/ op. cit. in /35/

/38/ op. cit. in /22/

/39/ op. cit. in /1/

/40/ Fulei, T.I., \& Kuchiv, A.M. (2017), Independence and impartiality of the court in relation to article 6 of the
Convention for the protection of human rights and fundamental freedoms: Practice of the ECHR in Ukraine. Kyiv: National School of Judges of Ukraine.

/41/ op. cit. in /7/

/42/ Hren, N.M. (2016), The right to a fair trial: the problems of independence and non-impartiality. Bulletin of the National University "Lviv Polytechnic", 837, 247-251.

/43/ Hlinska, N.V. (2017), The standard of impartiality of the prosecution in the understanding of Part 2 of Art. 9 of the Code of Criminal Procedure of Ukraine: meanings and criteria. Bulletin of Criminal Proceedings, 2, 25-32.

/44/ Barbakadze, E.T. (2014), Guarantees of an objective and fair trial of civil cases in ordinary civil process; arbitration process. Saratov: Saratov State Law Academy.

/45/ Rekhtina, I.V. (2010), On the state of quality of execution of court decisions. Russian Judge, 3 years old, 12-19.

/46/ Romaniuk, Yu. (2014), Reform of the judiciary in Ukraine. Law of Ukraine, 11, 119-126.

/47/ Tatulych, I.Yu. (2016), An impartial trial guarantees the achievement of the basic objectives of civil proceedings. Right State, 24, 154-158.

/48/ Shapovalova, Yu.V. (2018), Defects of judicial acts: concept, essence, consequences. Retrieved from https://www.researchgate.net/publication/322522684_Defekty_sudebnyh_aktov_ponatie_susnost_posledstvia

/49/ Novikovas, A., Novikoviene, L., Shapoval, R., \& Solntseva, K. (2017), The peculiarities of motivation and organization of civil defence service in Lithuania and Ukraine. Journal of Security and Sustainability Issues, 7(2), 369-380. 